\title{
Presence and potential role of thermophilic bacteria in temperate terrestrial environments
}

\footnotetext{
${ }^{1}$ IRNAS-CSIC, Avda. Reina Mercedes 10, Sevilla, 41012, Spain

${ }^{2}$ Department of Fitotecnia, Instituto de Ciências Agrárias e Ambientais Mediterrânicas, Universidade de Évora, 7002-774, Évora, Portugal
} 10

$15{ }^{\dagger}$ To whom correspondence should be addressed:

Juan M. Gonzalez,

Instituto de Recursos Naturales y Agrobiologia, IRNAS-CSIC,

Avda. Reina Mercedes 10, Sevilla, 41012, Spain.

Tel. +34 954624711 (ext. 146); Fax +34 954624002 .

20 E-mail: jmgrau@irnase.csic.es

Running title: Thermophiles in temperate terrestrial systems

25

Keywords: Thermophiles, Firmicutes, sulfate, ammonium, mineralization, temperate soils 


\footnotetext{
Abstract

30

Organic-sulfur and nitrogen are major reservoirs of these elements in terrestrial systems although their cycling remains to be fully understood. Both sulfur and nitrogen mineralization are directly related to microbial metabolism. Mesophiles and thermophiles were isolated from temperate environments. Thermophilic isolates were

35 classified within the Firmicutes, belonging to the Geobacillus, Brevibacillus and Ureibacillus genera, and showed optimum growth temperatures between $50^{\circ} \mathrm{C}$ and $60^{\circ} \mathrm{C}$. Sulfate and ammonium produced was higher during growth of thermophiles both for isolated strains and natural bacterial assemblages. Sulfate and ammonium produced were positively related to organic nutrient load. Temperature also affected the release of sulfate and ammonium by thermophiles. Quantitative, real-time RT-PCR on environmental samples indicated that the examined thermophilic Firmicutes represented up to $3.4 \%$ of total bacterial community RNA. Temperature measurements during summer days showed values above $40^{\circ} \mathrm{C}$ for over $10 \mathrm{~h}$ a day in soils from Southern Spain. These results support a potential role of thermophilic bacteria in temperate terrestrial environments by mineralizing organic sulfur and nitrogen ruled by the existence and length of warm periods.
} 


\section{Introduction}

50 Microorganisms are known to play essential roles in the biogeochemical cycling of elements (Torsvik et al. 2002; Crawford et al. 2005; Allison and Martiny 2008). Element cycling and the availability of inorganic nutrients for plant growth in terrestrial environments are topics of great interest. Understanding the potential sources of these nutrients as a function of environmental conditions is of critical importance for the

55 management of sustainable environments and agriculture.

A high fraction of the nitrogen in terrestrial environments is bound to organic matter (Gonzalez-Prieto and Carballas 1991). Nitrogen is one of the limiting elements for plant growth and fertilization is often required (Gruber and Galloway 2008). Most fertilizers

60 contain ammonium as a source of nitrogen which can be both incorporated and transformed by microorganisms. Nitrification is carried out by several microorganisms (e.g., Nitrosomonas, Nitrosospira) (Rowan et al. 2003) leading to nitrate which can be readily utilized by plants. One fate of inorganic nitrogen compounds from diverse sources is the synthesis of biomolecules and so, organic nitrogen (e.g., proteins) represents a major fraction of nitrogen in the environment. Organic matter also forms part of non-living matter (i.e., humic acids and dead biomass). Ammonium is an important source of nitrogen for microorganisms and plants and can be released into the environment, for instance, as a result of organic matter mineralization by ammonifying bacteria (Jarvis et al. 1996). Besides, the complexity of the nitrogen cycle is increasing as a result of recent investigation (Kartal et al. 2006). Organic content in soils and sediments constitute a nutrient reservoir for terrestrial system productivity which has been related to the capacity of soils to sustain plant growth (Gruber et al. 2008; Kreutzer et al. 2009).

75 Sulfur is another element required to maximize crop yields and quality (Tabatabai 1984; Wen et al. 2003). Most fertilizers relay on additions of elemental sulfur (Wen et al. 2003) although soluble sulfate is the major source of sulfur for plants. Sulfur mineralization is the conversion of organically bound sulfur to inorganic sulfate which is available to plants use (Eriksen 2008). Sulfur immobilization is the opposite process

80 in which inorganic sulfur is assimilated by the biota and incorporated into organic matter becoming unavailable to plant roots (Eriksen 2008; Schoenau and Malhi 2008). 
The processes responsible for sulfur transformations in soils, such as mineralization, immobilization, oxidation, and reduction, are mainly microbially mediated (Sparling and Searle 1993; Niknahad-Gharmakher et al. 2009). Factors affecting the microbial activity involved in these processes, such as $\mathrm{pH}$, temperature and nutrient availability have been scarcely studied.

In nature, sulfur is either in organic or inorganic forms. Organic sulfur represents most of the sulfur in soils with estimates of over 90\% of total sulfur (Schlesinger 1997;

90 Anandham et al. 2008). In unfertilized environments, mineralization is supposed to be the dominant input of sulfate for plant growth (Schoenau and Malhi 2008). However, under temperate conditions (around $20^{\circ} \mathrm{C}$ ), organic sulfur mineralization to sulfate has been reported to be highly limited (Ghani et al. 1993; Eriksen 1996). Heterotrophic sulfur-oxidizing bacteria have also been proposed as dominant in some soils, especially

95 in the rhizosphere (Grayston and Germida 1990), although the mesophilic microorganisms tested so far utilized mostly elemental sulfur, rather than organically bound sulfur, as source to generate sulfate (Grayston and Germida 1990; Kelly et al. 1997). Most studies of microbial sulfur cycling have been centered on transformations of inorganic sulfur by microorganisms, including sulfate-reducing (e.g., Desulfovibrio, 100 as the most cited genus) and inorganic sulfur-oxidizing (e.g., Beggiatoa, Sulfurimonas) bacteria (Kelly et al. 1997; Madigan et al. 2003) often related to the use of inorganic sulfur as fertilizer (Wen et al. 2003).

The presence of thermophilic bacteria in temperate environments has been previously 105 reported (Wiegel et al. 1979; Mutzel et al. 1996; Rahman et al. 2004). However, their function and possible ecological role remains to be understood. Huber et al. (Huber et al. 2009, 2010) reported the presence of thermophilic anaerobes in cold arctic marine sediments. Their existence in this cold environment was explained by the proximity of warm subsurface petroleum reservoirs. These thermophiles showed sulfate-reducing

110 activity around $50^{\circ} \mathrm{C}$ and were classified as Gram-positive bacteria related to the genus Desulfotomaculum. Marchant et al. $(2002,2008)$ have reported on the presence of thermophilic aerobic bacteria, mainly belonging to the genus Geobacillus, in cool temperate soils from North Ireland. These thermophiles grew above $40^{\circ} \mathrm{C}$ and showed optimum growth temperatures around $70^{\circ} \mathrm{C}$. Their function is unknown but they were 115 proposed to be endemic species at the studied sites (Marchant et al. 2002) in spite of the 
high rate of arrival of soil bacteria from the Sahara Desert (Portillo and Gonzalez, 2008; Perfumo and Marchant, 2010).

In this study, we report on a potential role for some thermophilic bacteria present in temperate terrestrial environments. We analyzed the physiological capabilities of some thermophiles on the mineralization of organic sulfur and nitrogen, producing sulfate and ammonium. Both isolates and natural bacterial communities were used throughout this study. The presence of active thermophiles and some of the opportunities to exploit their metabolism in temperate terrestrial environments are discussed.

\section{Materials and Methods}

Sampling. Samples for the isolation of microorganisms were collected from soil in

130 Southwestern Spain (Carmona, Seville; $37^{\circ} 28^{\prime} \mathrm{N}, 5^{\circ} 37^{\prime} \mathrm{W}$ ), from a pine forest soil and a nearby soil partially covered by weeds located in Northeastern Spain (Teruel, Aragon; $\left.40^{\circ} 24^{\prime} \mathrm{N}, 1^{\circ} 26^{\prime} \mathrm{W}\right)$. Seville represents one of the hottest areas of the Iberian Peninsula and Teruel shows a continental climate and is among the coldest Spanish provinces. These soils have been previously described (Navas and Machin 2002; Ordóñez-

135 Fernández et al. 2007). Samples for RNA extraction and quantification were also collected from an outlying area of Seville. Samples for RNA extraction and quantification were preserved in RNAlater (Ambion, Inc., Austin, TX) following the manufacturer's recommendations.

140 Experiments with thermophilic isolates. Cultures were carried out in nutrient broth (NB) which composition, per liter, was: 3 g beef extract and 5 g peptone. Nutrient agar had, in addition, $20 \mathrm{~g} \mathrm{l}^{-1}$ agar. Environmental samples were suspended in $0.9 \% \mathrm{NaCl}$ saline solution and vortexed; $100 \mu \mathrm{l}$ suspension were inoculated in nutrient agar and incubated for 3 days at $25^{\circ} \mathrm{C}$ or $50^{\circ} \mathrm{C}$, for mesophiles and thermophiles, respectively.

145 Colony forming units (CFU) of aerobic heterotrophic thermophiles were enumerated on nutrient agar plates incubated at $50^{\circ} \mathrm{C}$ for 3 days. Single colonies were transferred to fresh nutrient agar following three passes of isolation picking single colonies and following standard microbiological procedures. Isolates were identified by sequencing the small subunit of the rRNA gene. For bacterial isolates, the 16S rRNA genes were 
150 PCR amplified with the 27F (5’-AGA GTT TGA TYM TGG CTC AG) and 907R (5’CCC CGT CAA TTC ATT TGA GTT T) primer pair (Gonzalez et al. 2003). For the fungal isolate, the primer pair EukA (5’-AAC CTG GTT GAT CCT GCC AGT) and EukB (5'-TGA TCC TTC TGC AGG TTC ACC TAC) was used (Diez et al. 2001). The influence of temperature on the growth of the thermophiles was analyzed by OD determinations at $600 \mathrm{~nm}$ during incubation in NB with shaking (100 rpm) at different temperatures (from $20^{\circ} \mathrm{C}$ to $85^{\circ} \mathrm{C}$ ). The effect of temperature on the production of sulfate and ammonium by thermophilic isolates was examined as above at $50^{\circ} \mathrm{C}, 60^{\circ} \mathrm{C}$ and $70^{\circ} \mathrm{C}$.

160 Aliquots were collected overtime to estimate soluble sulfate concentration according to the method of Kolmert et al. (2000). Ammonium concentration was estimated according to Kartal et al. (2006). The produced sulfate and ammonium were estimated as the difference with respect to the initial concentration. Sterilized controls were carried out and used to estimate final levels of sulfate and ammonium during growth. All

165 experiments were performed in duplicate collecting triplicate aliquots for each measurement. Nitrate and nitrite were measured during preliminary experiments and we observed no significant increase of concentration during the growth of the isolated thermophiles. The concentration of nitrate was at the lowest limit of detection $(0.5 \mathrm{mM})$ for the method used (Cataldo et al. 1975).

Thermophilic isolates were grown in NB with and without supplemented sodium thiosulfate (3 mM) to test its influence on sulfate production. Thiosulfate is a major intermediate in the inorganic oxidation of sulfur and sulfide to sulfate for a number of bacteria (Kelly et al. 1997; Madigan et al. 2003). To evaluate the production of $\mathrm{H}_{2} \mathrm{~S}$ as a

175 potential source for sulfate after its oxidation the concentration of $\mathrm{H}_{2} \mathrm{~S}$ was determined in cultures at exponential and stationary phases of growth using $\mathrm{H}_{2} \mathrm{~S}$ electrodes (Unisense, Aarhus, Denmark). $\mathrm{H}_{2} \mathrm{~S}$ was undetectable during the whole duration of the experiments and the initial concentration of sulphate in NB medium was $1 \mathrm{mM}$.

180 Thermophilic isolates were grown at different concentrations of NB (from $0.01 \mathrm{x}$ to $2 \mathrm{x}$ ) to assess the effect of organic nutrients on sulfate and ammonium production. Standard concentration of NB (1x) contained $5 \mathrm{~g}$ peptone and $3 \mathrm{~g}$ beef extract per liter. Biomass obtained during growth was estimated as cellular protein content and determined by the 
Bradford method (Bradford Protein Assay, BioRad, Hercules, CA). Sulfate and ammonium concentrations were normalized by the biomass produced during growth.

Experiments with natural bacterial assemblages. Samples ( $5 \mathrm{~g}$ ) were incubated in 10 $\mathrm{ml}$ nutrient broth (NB) in a shaker $(250 \mathrm{rpm})$ at $25^{\circ} \mathrm{C}$ and $50^{\circ} \mathrm{C}$. Treatments using these natural bacterial assemblages were performed in duplicate. Aliquots (in triplicate) were

190 collected overtime to estimate soluble sulfate and ammonium concentration as described above.

In situ relative rRNA quantification. Relative quantification of ribosomal RNA (rRNA) from thermophilic Firmicutes (represented in the genera Brevibacillus,

195 Geobacillus and Ureibacilllus) was performed from environmental samples. The rRNA has been used as indicator of metabolic activity by bacteria (Molin and Givskov 1999; Portillo et al. 2009). Quantification of RNA belonging to the selected thermophilic Firmicutes with respect to total bacterial RNA was carried out by quantitative, real-time RT-PCR. Total RNA was extracted with the RNAqueous4-PCR kit (Ambion, Inc.,

200 Austin, TX). The protocol for total RNA extraction included DNaseI treatment to remove any DNA remaining in the final RNA extract.

Reverse-transcription PCR (RT-PCR) was performed using oligonucleotides targeting the 16S-23S rRNA gene internal transcribed spacer (ITS) of the genus Geobacillus

205 (Kuisiene et al. 2007) and newly designed oligonucleotides targeting the 16S rRNA genes of the known thermophilic representatives of the genera Brevibacillus, Geobacillus and Ureibacillus. The primers targeting the ITS were GeobacF (forward; 5’-TAA GCG TGA GGT CGG TGG TTC) and GeobacR (reverse; 5'-GCG CTC TCG GCT TCT TCC TT) (Kuisiene et al. 2007) which resulted in amplicons of about 300 bp.

210 The 16S rRNA genes of the thermophilic Firmicutes belonging to the three selected genera were targeted by amplifications combining the forward primers Geo485F (5'CTG ACG GAG CGA CGC CGC GTG AGC) and B-U485F (5’-CTG ATG GAG CAA CGC CGC GTG ARC) and the reverse primer 518R (5'-ATT ACC GCG GCT GCT GG). The forward primers Geo485F and B-U485F were designed to target Geobacillus, 215 and the thermophilic representatives of the genera Brevibacillus and Ureibacillus, respectively. The forward primer mix was composed by $50 \%$ of each primer, Geo485F 
and B-U485F. Total bacterial RNA was amplified by using the primer pair 341F (5'-CC TAC GGG AGG CAG CAG) (Lane 1991) and 518R (Neefs et al. 1990).

220 Reverse transcription reactions were carried out using Thermoscript (Invitrogen, Carlsbag, CA) at $55^{\circ} \mathrm{C}$ using the reverse primers. Quantitative PCRs were performed with the SensiMix SYBR \& Fluorescein Kit for real-time PCR (Quantace, Germany) on a thermocycler iQ iCycler (Bio-Rad, Hercules, CA). Triplicate reactions were processed under the following cycling conditions: $95^{\circ} \mathrm{C}$ for $5 \mathrm{~min}$ and 50 cycles of a denaturing

225 step at $95^{\circ} \mathrm{C}$ for $15 \mathrm{~s}$, annealing at $62^{\circ} \mathrm{C}$ for $15 \mathrm{~s}$, extension at $72^{\circ} \mathrm{C}$ for $30 \mathrm{~s}$, and a final step for the measurement of SYBR Green fluorescence at $80^{\circ} \mathrm{C}$ for $10 \mathrm{~s}$. Relative quantitative PCR estimates were performed according to the sigmoidal non-linear curve-fitting method described by Rutledge (2004). Relative quantitative estimates of thermophilic Firmicutes RNA were normalized with those from total bacterial RNA.

Environmental temperature measurements. Environmental temperatures were measured using a K-thermocouple thermometer (Hanna Instruments, Ann Arbor, Michigan, USA). Surface and $2 \mathrm{~cm}$ depth measurements were performed throughout a day period at a soil of an outlying area of Seville (Spain). Air temperature was

235 determined at about $1 \mathrm{~m}$ from soil surface.

Statistical analysis. Significant differences $(\mathrm{P}<0.05)$ among treatments were compared through ANOVA (Sokal and Rohlf 1981).

\section{Results}

Different isolates were obtained from sediments and soils at distinct Spanish locations at Southwestern and Northeastern areas showing significant climatic differences. A list

245 of these isolates is shown in Table 1 and they were among the most common culturable bacteria at $25^{\circ} \mathrm{C}$ and $50^{\circ} \mathrm{C}$ from the studied sites. The mesophilic bacterial isolates were identified by 16S rRNA gene sequencing and belonged to the Actinobacteria (Cellulomonas and Streptomyces), Firmicutes (Paenibacillus), and Gammaproteobacteria (Enterobacter and Klebsiella). A fungus (Neocosmospora) was 250 also isolated. The isolated thermophiles were all members of the Order Bacillales 
(Firmicutes) and were represented by the genera Bacillus, Brevibacillus, Geobacillus, and Ureibacillus. No growth was observed under anaerobic conditions. Culturable thermophiles averaged $4.5 \pm 1.3 \times 10^{5} \mathrm{CFU} / \mathrm{g}$ for the studied samples. Thermophilic isolates were used as models to study the microbial capacity to release sulfate and ammonium during growth.

In general, cultures of thermophilic isolates produced higher levels of soluble sulfate than the mesophilic strains (Fig. 1). The growth of the mesophiles $\left(25^{\circ} \mathrm{C}\right)$ showed low to insignificant levels of soluble sulfate in the medium along their growth curve. Although leading to much lower soluble sulfate concentrations, some of the mesophiles resulted in a significant increase in the release of sulfate during the stationary phase of growth (i.e., strains 1 and 6). Other bacterial mesophiles (i.e., strain 4) showed a consumption of soluble sulfate during the stationary phase of growth. Bacterial strain 2 and the fungal strain 5 did not show significant increase of soluble sulfate during the growth curve.

The concentration of sulfate varied along the growth curve of the thermophilic isolates and it was strain dependent. Maximum growth yields reach in the cultures of the

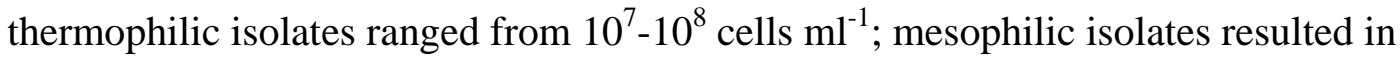
yields of at least $10^{8}$ cells $\mathrm{ml}^{-1}$. Figure 1 shows the increase of sulfate in thermophilic 270 cultures incubated for 1 day (exponential phase of growth) and 8 days (stationary phase of growth). Some of the thermophiles (i.e., strains 7, 10, and 12) presented an increase of soluble sulfate during their stationary phase of growth. Other thermophiles (strains 8, 9, and 11) showed no significant changes in the amount of sulfate released during the stationary phase of growth. These results suggested a production of soluble sulfate

275 during the growing phase and, in addition, some strains were able to continue the release of sulfate to the medium during the stationary phase of the growth curve.

In order to verify the thermophily of the high temperature isolates from this work, the influence of temperature on growth rate was examined. The optimum growth rates for these isolates were between $50^{\circ} \mathrm{C}$ and $60^{\circ} \mathrm{C}$. No growth was detected in cultures of these thermophilic isolates below $40^{\circ} \mathrm{C}$ and above $80^{\circ} \mathrm{C}$.

Temperature had a significant influence on the release of soluble sulfate by thermophiles. Figure 2 showed the concentration of soluble sulfate in the cultures of the 
285 isolated thermophiles at different temperatures. The release of sulfate was strain dependent. Strains 7 and 9 showed a significant increase in the concentration of soluble sulfate at $70^{\circ} \mathrm{C}$ about $10^{\circ} \mathrm{C}$ above the optimum for these two strains. No significant release of soluble sulfate was detected for strains 7 and 9 at $50^{\circ} \mathrm{C}$. Strains 8 and 10 showed maximum production of soluble sulfate at $60^{\circ} \mathrm{C}$, approximately at their optimum growth temperature. However, strain 10 showed a significant reduction of sulfate production at $50^{\circ} \mathrm{C}$ and $70^{\circ} \mathrm{C}$ and strain 8 maintained an elevated sulfate release at $70^{\circ} \mathrm{C}$. Strain 11 showed no production of sulfate at $70^{\circ} \mathrm{C}$ and strain 12 showed maximum production of soluble sulfate at $50^{\circ} \mathrm{C}$ and poor to null sulfate released at $60^{\circ} \mathrm{C}$ and $70^{\circ} \mathrm{C}$.

295

An intermediate of the oxidation of inorganic sulfur is thiosulfate (Kely et al. 1997; Madigan et al. 2003). Most bacteria carrying out inorganic sulfur-oxidation are able to further oxidize thiosulfate to sulfate. To test if the thermophilic isolates analyzed in this study were inorganic sulfur oxidizing bacteria, sulfate concentrations were monitored 300 during growth with and without addition of thiosulfate. Results showed similar sulfate concentrations in supplemented and unsupplemented cultures (Fig. 3). The production of $\mathrm{H}_{2} \mathrm{~S}$ by the thermophilic isolates (which could be chemically oxidized to sulfate) was ruled out because none of these isolates were $\mathrm{H}_{2} \mathrm{~S}$ producers.

305 Environmental samples were incubated at $25^{\circ} \mathrm{C}$ and $50^{\circ} \mathrm{C}$ to determine if bacterial assemblages, rather than isolates, also resulted in similar effects on the concentrations of soluble sulfate. Figure 4A shows that higher concentrations of soluble sulfate were reached at $50^{\circ} \mathrm{C}$ than at $25^{\circ} \mathrm{C}$. The concentration of sulfate produced at $50^{\circ} \mathrm{C}$ was from 2- to 5 -fold the levels measured at $25^{\circ} \mathrm{C}$.

The release of ammonium during growth of natural bacterial assemblages resulted in similar or higher concentrations at $50^{\circ} \mathrm{C}$ than at $25^{\circ} \mathrm{C}$ (Fig. 4B). The ammonium produced by communities of thermophiles was from non-significant differences up to over 2-fold the levels reached by the mesophilic assemblages.

To evaluate the influence of nutrient concentration on the release of sulfate and ammonium by thermophiles, two isolates were selected (strains 10 and 12; Table 1). In general, the lowest nutrient concentrations showed the lowest levels of sulfate and 
ammonium (Fig. 5). Produced sulfate and ammonium were related to nutrient availability (Fig. 5). The values of organic carbon (8 g organic nutrients $\mathrm{L}^{-1}$ ) in the growth experiments were close to the range of environmental estimates of organic carbon in soils (from 10 to $200 \mathrm{~g} \mathrm{C} \mathrm{Kg}^{-1}$ ) recently reported (Calderon et al. 2011; Martínez-Lladó et al. 2011; Sleutel et al. 2011). Higher concentration of sulfate and ammonium was measured during the stationary phase of growth (6 days incubation)

325 than during the strains exponential phase. The production of sulfate showed maximum yield levels at 1.5x NB and a slight inhibition at higher nutrient loads (Figure 5A and C). About the production of ammonium, similar results were observed for strain 10 (Figure 5B) although strain 12 showed a continuous increase of produced ammonium for the evaluated range of nutrient concentrations (Figure 5D).

In environmental samples, the presence of active thermophiles of the studied group was determined by quantitative RT-PCR. The relative fraction of RNA from these thermophiles was detectable in the studied samples. A maximum proportion of thermophilic Firmicutes RNA of 3.14\% was detected in the studied bacterial communities (Table 2). Fractions from $0.029 \%$ to 3.14\% of thermophilic Firmicutes RNA (within the studied genera) with respect to total bacterial RNA were measured in different samples. Although different factors could be involved in the levels of RNA from these thermophiles in natural environments, an exponential relationship was observed between RNA of these thermophiles and soil temperature for most of the 340 studied communities. This corroborates a positive effect of temperature on the activity of thermophilic Firmicutes. This relationship was represented by the equation $\left(r^{2}=0.97\right.$; $\mathrm{n}=6): \mathrm{Y}=0.1115 \exp (0.053 \mathrm{~T})$, where $\mathrm{T}$ is temperature $\left({ }^{\circ} \mathrm{C}\right)$ and $\mathrm{Y}$ is the percentage of RNA from the studied thermophilic Firmicutes with respect to total bacterial community RNA. However, two samples showing the lowest thermophilic Firmicutes 345 RNA content appeared to present a parallel relationship, likely due to the effect of other environmental factors inducing low levels of Bacillales RNA.

The possibility of reaching temperatures adequate for the growth of the analyzed thermophiles in natural ecosystems was examined by measuring surface and $2 \mathrm{~cm}$ depth temperatures along a $24 \mathrm{~h}$ period for a soil in Southwest Spain (Carmona, Seville, Spain) (Fig. 6). These measurements were carried out during a mild summer day at the studied location. Maximum air temperature was around $40^{\circ} \mathrm{C}$ during the early afternoon. 
Temperatures of and above $40^{\circ} \mathrm{C}$ were measured in the soil for about $10 \mathrm{~h}$ a day. Maximum temperature at this occasion was $62^{\circ} \mathrm{C}$ and $57^{\circ} \mathrm{C}$ at the soil surface and $2 \mathrm{~cm}$ depth, respectively.

\section{Discussion}

360 The current concept of microbial communities in the environment highlights the elevated diversity existing in natural systems (Curtis et al. 2002; Pedrós-Alió 2006). According to our understanding of these communities, they are composed by low number of highly abundant microbial taxa and an unimaginable high number of poorly represented microbial phylotypes (Pedrós-Alió 2007). Thermophilic microorganisms

365 might be a group among those low abundant microbial taxa and they could play a role in some temperate terrestrial, as well as arid, systems, at least, within a seasonal periodicity.

At present, there are numerous reports on the cultivation, isolation, and classification of thermophilic strains from temperate environments (Wiegel et al. 1997; Mutzel et al. 1996; Rahman et al. 2004). However, few studies have actually dealt with the presence, biogeography, and potential impact of thermophiles in temperate environments. Marchant et al. (2002) analyzing North Ireland soils detected culturable thermophiles in every sampled site although their environmental role remained to be elucidated. Studies

375 by Huber et al. (Huber et al. 2009, 2010) reported on the stable presence of sulfatereducing thermophiles in cold arctic sediments. They could originate from nearby warm petroleum reservoir systems (Huber et al. 2009). Our study confirms the existence of culturable thermophiles in different Spanish soils. The cultured thermophiles were classified as members of the order Bacillales (Firmicutes), specifically within the genera

380 Bacillus, Brevibacillus, Geobacillus and Ureibacillus, which is in agreement to the strains of Geobacillus reported by Marchant et al. (2002) in Irish soils. The abundance of culturable thermophiles was about one order of magnitude higher in the present study than in a previous report (Marchant et al. 2001) which can be a consequence of the lower temperatures in North Ireland soils (up to $15^{\circ} \mathrm{C}$ ) (Marchant et al. 2002) than at some of the soils in Southwestern Spain. 
Environmental soil bacterial assemblages and different bacterial isolates were analyzed for soluble sulfate and ammonium production during growth. At the thermophilic temperature range higher soluble sulfate and similar to higher ammonium were produced than by mesophiles. The final concentrations of ammonium obtained in the experiments with thermophilic isolates were at similar levels than those reported for hyper-ammonia producing bacteria (Eschenlauer et al. 2002; Whitehead and Cotta 2004) suggesting a similar high potential for $\mathrm{N}$ mineralization. The origin of the sulfate and ammonium was the organic matter consumed during the metabolism of these 395 thermophiles. Most heterotrophic sulfur-oxidizing bacteria are able to further oxidize thiosulfate to sulfate (Kelly et al. 1997; Madigan et al. 2003). Experiments of cultures supplemented with thiosulfate failed to show differences in soluble sulfate concentrations for different thermophilic strains. These results suggest that the isolated thermophiles did not produce sulfate oxidizing inorganic sulfur sources rather it

400 represents a dissimilative organic-sulfur oxidizing process that mineralizes organically bound sulfur producing sulfate. The ammonium produced by the studied thermophiles is a result of the decomposition of organic matter (e.g., proteins) as reported for the heterotrophic ammonifying bacteria within the mesophiles (Eschenlauer et al. 2002; Whitehead and Cotta 2004).

405

Growth of the studied thermophiles under different concentrations of nutrients showed that soluble sulfate and ammonium was produced at higher concentrations as the availability of organic nutrients increased. As well, sulfate and ammonium production occurred both during the exponential and the stationary phase of growth suggesting that organic matter consumed for growth and the organic molecules processed during maintenance/survival stages lead to the release of the exceeding sulfur and nitrogen as sulfate and ammonium, respectively. The effect of temperature on sulfate and ammonium production by these thermophiles was strain dependent. Some strains produced higher sulfate at near their maximum growth temperature (i.e., $70^{\circ} \mathrm{C}$ ), others

415 achieved maximum sulfate concentrations at temperatures close to their optimum for growth $\left(50^{\circ} \mathrm{C}\right.$ and $\left.60^{\circ} \mathrm{C}\right)$ and some were unable to reach detectable production of sulfate under high temperature stress conditions (i.e., $70^{\circ} \mathrm{C}$ ). The above suggests that the diversity of these thermophiles could complement environmental requirements allowing changes in soil communities as a function of temperature and availability of organic nutrients during heated periods. 
Sulfur and nitrogen are elements often limiting plant growth (Tabatabai 1984; Wen et al. 2003). Interestingly, most sulfur ( $>90 \%)$ in soils is bound to organic matter (Schlesinger 1997; Anandham et al. 2008). As well, a large fraction of nitrogen (>95\%) 425 form part of biomolecules and humic acids (Gonzalez-Prieto and Carballas 1991; Madigan et al. 2003). Thus, the mineralization of sulfur and nitrogen represents major sources of inorganic nutrients for plant growth (Gruber and Galloway 2008; Schoenau and Malhi 2008). Previous studies carried out in the mesophilic temperate range (around $20^{\circ} \mathrm{C}$ ) have shown that bacterial mineralization of organic-sulfur as sulfate is poor in 430 soils (Eriksen 1996; Ghani et al. 2001). As a result, the potential role of thermophiles as sulfur and nitrogen mineralizers during warm seasonal periods should be considered a pathway for the natural fertilization of soils, above all, in warm and arid environments.

Bacterial thermophiles were expected to only represent a minority within temperate soil 435 bacterial communities. Their presence as detectable metabolically active bacteria in the environment suggests that their mechanisms of persistence and participation in environmental processes should be considered. The detection of RNA from a specific bacterial group in complex communities have been reported to be a direct indicator of the occurrence of that microbial group as a metabolically active component of the 440 bacterial community (Molin and Givsov 1999; Portillo et al. 2009). In this study, the RNA of thermophiles within the Bacillales was targeted by quantitative RT-PCR. Results confirmed that these thermophiles represented detectable fractions of the bacterial RNA in soil communities, reaching up to $3.14 \%$ of total bacterial community. This relative quantification was analyzed as a function of sample temperature indicating 445 that the portion of thermophilic RNA in soil bacterial communities directly depends on temperature even if other factors can also influence the activity of these thermophiles. Although the analysis of the factors (besides temperature) affecting the level of RNA from thermophiles in soils needs to be studied in detail, we suggest that the availability of organic nutrients might significantly affect the metabolism of the group of thermophilic microorganisms under analysis.

To assess if thermophiles could have a chance to develop in temperate terrestrial environments, it is important to evaluate whether these soils can reach the temperature range of growth for these thermophiles. Results presented in this study, as well as those 
455 by Marchant et al. (2002), report no visible growth below $40^{\circ} \mathrm{C}$. Whereas Marchant et al. (2002) reported that North Ireland soil temperatures reach at most $15^{\circ} \mathrm{C}$, higher latitudes such as southern European countries surrounding the Mediterranean Sea, and areas at similar latitude, could easily present soil temperatures above $40^{\circ} \mathrm{C}$ during warm seasons. More extreme environments such as arid and desert locations have reported even higher temperatures. For instance, temperatures above $50^{\circ} \mathrm{C}$ are common in arid regions of Africa and America (McCalley and Sparks 2009). Mojave Desert mid-day soil temperatures are $>65^{\circ} \mathrm{C}$ and can exceed $90^{\circ} \mathrm{C}$ (McCalley and Sparks 2009). These results confirm that soil temperatures at a wide range of latitudes can be within the temperature range required for the reported thermophiles to grow.

It is known that spore-forming bacteria (as is the case for many Bacillales) can survive for extremely long periods. However, previous discussion (Marchant et al. 2002, 2008) as well as the RNA results presented in this study confirm that at least a fraction of these thermophiles actually exist as vegetative forms. The possibility of very slow but

470 continuous growth of thermophiles at low temperatures has been recently proposed (Marchant et al. 2008) and can account for the maintenance of viable thermophiles in cold temperate environments (Jones and Lennon 2010). In cold temperate environments, such as low latitude locations, these survival strategies (Marchant et al. 2008; Jones and Lennon 2010) offer an explanation to the ubiquitous presence of 475 thermophiles (Boyd and Boyd 1962; Wiegel et al. 1979; Rahman et al. 2004). This mechanism of survival and the detection of these thermophiles as metabolically active cells within the bacterial communities indicate that the thermophiles under study show vegetative stages and metabolic activity even at temperatures lower than their typical range for growth. Thus, thermophiles inhabiting low-medium latitude and medium-high 480 latitude locations might be showing different survival strategies. Those at the cold temperate sites could base their survival on the slow, long term, growth alternative. However, thermophiles at warmer places could have the chance to grow at higher rates at least during short time periods annually. Under both scenarios, thermophiles might likely be adapted to thrive under adverse environments (the dominating low temperatures) waiting until adequate conditions (i.e., temperature increase) permit their normal development allowing them to compete with, or partially replace, mesophiles. The occurrence of minority groups, such as the thermophiles, within the rare biosphere (Huber et al. 2010; Jones and Lennon 2010; Pedrós-Alió 2007) could represent a 
microbial seed bank able to redraw the community if a change of the environmental conditions arises.

An extensive debate can be maintained about the ultimate origin of the thermophiles, mainly Firmicutes, in temperate environments. Some results point to the existence of both short and long distance dispersal from hot environments by fluids, such as wind or 495 water currents (Kellogg and Griffin 2006; Portillo and Gonzalez 2008; Huber et al. 2009; Perfumo and Marchant 2010). Current studies on the dispersal of particles from the Sahara Desert to European and America (Kellogg and Griffin 2006; Hervás et al. 2009; Perfumo and Marchant 2010) represent a serious support for this theory. The possibility of an onsite speciation and adaptation to exploit specific spatial and temporal

500 niches as a result of a long period of evolution could also be argued in some cases, such as this study. Independently of the actual mechanisms that allowed thermophiles to reach these environments and in agreement to these two hypothesis and previous reports (Marchant et al. 2002), different lines of evidence support that, at present, these thermophiles represent endemic taxa and established minorities within bacterial communities in temperate environments. The potential for thermophiles to incorporate into the mineralization of organic matter and the sulfur and nitrogen cycling during warm seasons (i.e., under a seasonal periodicity) is proposed.

Because temperature is a decisive factor for the proposed role of thermophiles in 510 temperate terrestrial environments, the expected increase in periodicity of extreme heat events and average temperature due to the on-going global climate change (IPCC 2007; Battisti and Naylor 2009) points towards an enhancement of the actual significance of thermophiles in temperate environments. An increase of mean annual temperatures will imply an increasing frequency of extreme heat events and high temperature conditions

515 during summer periods (Melillo et al. 2002; Battisti and Naylor 2009) which should favor conditions for the development of thermophiles and their metabolic activity. Besides, there is a major lack of knowledge on the potential consequences of climate change on the environment (Melillo et al. 2002; Lobell and Burke 2008), and specifically on microbial communities and their implications on the ecosystems.

520 Thermophilic Firmicutes could represent model microorganisms that can be identified to evaluate future global warming changes on microbial communities. 


\section{Conclusions}

525

Results presented in this study suggest that thermophiles could represent an important fraction of the microbial communities that should be considered to fully understand the functioning of temperate terrestrial environments. These thermophiles could actively participate in promoting organic matter mineralization producing sulfate and

530 ammonium during warm periods. In this scenario, thermophiles could have a niche and opportunity to actively participate in sulfur and nitrogen cycling from organic matter in temperate soil environments during summer periods when mesophiles would be either dormant or under maintenance/survival stages of their living cycle.

\section{Acknowledgements}

This work was supported through projects from Spanish Ministry of Science and Innovation (CGL2009-12328/BOS; CSD2009-00006), and the regional governments of 540 Aragón (PM055/2006) and Andalusia (BIO-288). The participation of Feder funds in these projects is acknowledged.

\section{References}

545

Allison SD, Martiny JBM (2008) Resistance, resilience, and redundancy in microbial communities. Proc Natl Acad Sci USA 105:11512-11519

Anandham R, Indiragandhi P, Madhaiyan M, Ryu KY, Jee HJ, Sa TM (2008) Chemolithoautotrophic oxidation of thiosulfate and phylogenetic distribution of sulfur oxidation gene (soxB) in rhizobacteria isolated from crop plants. Res Microbiol 159:579-589

Battisti DS, Naylor RL (2009) Historical warnings of future food insecurity with unprecedented seasonal heat. Science 323:240-244

Boyd WL, Boyd JW (1962) Viability of thermophiles and coliform bacteria in arctic soils and water. Can. J. Microbiol. 8, 189-192. 
Calderon F, Reeves JB, Collins HP, Paul EA (2011) Chemical differences in soil organic matter fractions determined by diffuse-reflectance mid-infrared spectroscopy. Soil Sci Soc Am J 75:568-579

Cataldo DA, Haroon M, Schrader LE, Youngs VL (1975) Rapid colorimetric determination of nitrate in plant-tissue by nitration of salicylic-acid. Commun Soil Sci Plant Anal 6:71-80

Crawford JW, Harris JA, Ritz K, Young IM (2005) Towards an evolutionary ecology of life in soil. Trends Ecol Evol 20:81-87

Curtis TP, Sloan WT, Scannell JW (2002) Estimating prokaryotic diversity and its limits. Proc Natl Acad Sci USA 99:10494-10499

Diez B, Pedros-Alio C, Marsh TL, Massana R (2001) Application of denaturing gradient gel electrophoresis (DGGE) to study the diversity of marine picoeukaryotic assemblages and comparison of DGGE with other molecular techniques. Appl Environ Microbiol 67:2942-2951

570 Eriksen J (1996) Incorporation of S into soil organic matter in the field as determined by the natural abundance of stable S isotopes. Biol Fertil Soils 22:149-155.

Eriksen J (2008) Soil sulfur cycling in temperate agricultural systems. In: Jez, J. (ed) Sulfur: a missing link between soils, crops and nutrition. American Society of Agronomy Inc., Madison, WI, pp 25-44

575 Eschenlauer SCP, McKain N, Walker NA, McEwan NR, Newbold CJ, Wallace RJ (2002) Ammonia production by ruminal microorganisms and enumeration, isolation, and characterization of bacteria capable of growth on peptides and amino acids from the sheep rumen. Appl Environ Microbiol 68:4925-4931

Ghani A, McLaren RG, Swift RS (1993) Mobilization of recently-formed soil organic 580 sulphur. Soil Biol Biochem 25:1739-1744

Golterman HL (1995) The labyrinth of nutrient cycles and buffers in wetlands: result based on research in the Camargue (Southern France). Hydrobiologia 315:39-58

Gonzalez JM, Ortiz-Martinez A, Gonzalez-del Valle MA, Laiz L, Saiz-Jimenez C (2003) An efficient strategy for screening large cloned libraries of amplified 16S rDNA sequences from complex environmental communities. J Microbiol Meth 55:459-463

Gonzalez-Prieto SJ, Carballas T (1991) Composition of organic N in temperate humid region soils (NW Spain). Soil Biol Biochem 23:887-895 
Grayston SJ, Germida JJ (1990) Influence of crop rhizosphere on populations and activity of heterotrophic sulfur-oxidizing microorganisms. Soil Biol Biochem 22:457-463

Gruber N, Galloway JN (2008) An earth-system perspective of the global nitrogen cycle. Nature 451:293-296

Hervás A, Camarero L, Reche I, Casamayor EO (2009) Viability and potential for immigration of airborne bacteria from Africa that reach high mountain lakes in Europe Environ Microbiol 11:1612-1623

Huber C, Loy A, Nickel M, Arnosti C, Baranyi C, Brüchert V, Ferdelman T, Finster K, Christensen FM, de Rezende JR, Vandieken V, Jørgensen BB (2009) A constant flux of diverse thermophilic bacteria into the cold arctic seabed. Science 325:15411544

Huber C, Arnosti C, Brüchert V, Loy A, Vandieken V, Jørgensen BB (2010) Thermophilic anaerobes in Arctic marine sediments induced to mineralize complex organic matter at high temperature. Environ Microbiol 12:1089-1104

Intergovernmental Panel on Climate Change (IPCC) (2007) Fourth Assessment Report: Synthesis. http://www.ipcc.ch/ipccreports/ar4-syr.htm

Jarvis SC, Stockdale EA, Shepherd MA, Powlson DS (1996) Nitrogen mineralization in temperate agricultural soils: processes and measurement. Adv Agron 57:187-235

Jones SE, Lennon JT (2010) Dormancy contributes to the maintenance of microbial diversity. Proc Natl Acad Sci USA 107:5881-5886

610 Kartal B, Koleva M, Arsov R, van der Star W, Jetten MSM, Strous M (2006) Adaptation of a freshwater anammox population to high salinity wastewater. J Biotechnol 126:546-553

Kellogg CA, Griffin DW (2006) Aerobiology and the global transport of desert dust. Trends Ecol Evol 21:638-644

615 Kelly DP, Shergill JK, Lu W-P, Wood AP (1997) Oxidative metabolism of inorganic sulfur compounds by bacteria. Ant van Leeuw Intl J Microbiol 71:95-107

Kolmert A, Wikström P, Hallberg KB (2000) A fast and simple turbidimetric method for the determination of sulfate in sulfate-reducing bacterial cultures. J Microbiol Meth 41:179-184

620 Kreutzer K, Butterbach-Bahl K, Rennenberg H, Papen H (2009) The complete nitrogen cycle of an N-saturated spruce forest ecosystem. Plant Biol 11:643-649 
Kuisiene N, Raugalas J, Stuknyte M, Chitavichius D (2007) Identification of the genus Geobacillus using genus-specific primers, based on the 16S-23S rRNA gene internal transcribed spacer. FEMS Microbiol Lett 277:165-172

625 Lane DJ (1991) 16S/23S rRNA sequencing. In: Stackebrandt E, Goodfellow M (eds) Nucleic acid techniques in bacterial systematic. Wiley, Chichester, pp 205-248 Lobell DB, Burke MB (2008) Why are agricultural impacts of climate change so uncertain? The importance of temperature relative to precipitation. Environ Res Lett 3:034007

630 Madigan M, Martinko JM, Parker J (2003) Brock Biology of Microorganisms. Prentice Hall Inc., New Jersey

Marchant R, Banat IM, Rahman TJ, Berzano M (2002) The frequency and characteristics of highly thermophilic bacteria in cool soil environments. Environ Microbiol 4:595-602

635 Marchant R, Franzetti A, Pavlostathis SG, Tas DO, Erdbrügger I, Unyayar A, Mazmanci MA, Banat IM (2008) Thermophilic bacteria in cool temperate soils: are they metabolically active or continually added by global atmospheric transport? Appl Microbiol Biotechnol 78:841-852

Martínez-Lladó X, Valderrama C, Rovira J, Marti V, Giménez J, de Pablo J (2011)

640 Sorption and motility of $\mathrm{Sb}(\mathrm{V})$ in calcareous soils of Catalonia (NE Spain): Batch and column experiments. Geoderma 160:468-476

McCalley CK, Sparks JP (2009) Abiotic gas formation drives nitrogen loss from a desert ecosystem. Science 326:837-840

Melillo JM, Steudler PA, Aber JD, Newkirk K, Lux H, Bowles FP, Catricala C, Magill

645 A, Ahrens T, Morrisseau S (2002) Soil Warming and Carbon-Cycle Feedbacks to the Climate System. Science 298:2173-2176

Molin S, Givskov M (1999) Application of molecular tools for in situ monitoring of bacterial growth activity. Environ Microbiol 1:383-391

Mutzel A, Reinscheid UM, Antranikian G, Müller R (1996) Isolation and 650 characterization of a thermophilic Bacillus strain, that degrades phenol and cresols as sole carbon and energy source at $70^{\circ} \mathrm{C}$. Appl Microbiol Biotechnol 46:593-596

Navas A, Machin J (2002) Spatial distribution of heavy metals and arsenic in soils of Aragón (Northeast Spain): controlling factors and environmental implications. Appl Geochem 17:961-973 
655 Neefs JM, van de Peer Y, Hendriks L, de Wachter R (1990) Compilation of small ribosomal subunit RNA sequences. Nucl Acids Res 18:2237-2317

Niknahad-Gharmakher H, Delfosse O, Chauveau-Duriot B, Andueza D, Cornu A (2009) Estimation of sulfur mineralization and relationships with nitrogen and carbon in soils. Biol Fert Soils 45:297-304

660 Ordóñez-Fernández R, González-Fernández P, Giráldez-Cervera JV, Perea-Torres F (2007) Soil properties and crop yields after 21 years of direct drilling trials in Southern Spain. Soil Tillage Res 94:47-54

Pedrós-Alió C (2006) Marine microbial diversity: can it be determined? Trends Microbiol 14:257-263

665 Pedrós-Alió C (2007) Dipping into the rare biosphere. Science 315:192-193

Perfumo A, Marchant R (2010) Global transport of thermophilic bacteria in atmospheric dust. Environ Microbiol 2:333-339

Portillo MC, Gonzalez JM (2008) Microbial communities and immigration in volcanic environments of Canary Islands (Spain). Naturwissenschaften 95:307-315

670 Portillo MC, Sririn V, Kanoksilapatham W, Gonzalez JM (2009) Differential microbial communities in hot spring mats from Western Thailand. Extremophiles 13:321-331

Rahman TJ, Marchant R, Banat IM (2004) Distribution and molecular investigation of highly thermophilic bacteria associated with cool soil environments. Biochem Soc Transactions 32:209-213

675 Rowan AK, Snape JR, Fearnside D, Barer MR, Curtis TP, Head IM (2003)

Composition and diversity of ammonia-oxidising bacterial communities in wastewater treatment reactors of different design treating identical wastewater. FEMS Microbiol Ecol 43:195-206

Rutledge RG (2004) Sigmoidal curve-fitting redefines quantitative real-time PCR with 680 the prospective of developing automated high-throughput applications. Nucl Acids Res 32:e178

Schlesinger WH (1997) Biogeochemistry, second edn. Academic Press, San Diego, CA

Schoenau JJ, Malhi SS (2008) Sulfur forms and cycling processes in soil and their relationship to sulfur fertility. In: Jez J (ed) Sulfur: a missing link between soils, crops and nutrition. American Society of Agronomy Inc., Madison, WI, pp 1-10

Sleutel S, Leinweber P, van Ranst E, Kader MA, Jegajeevagan K (2011) Organic matter in clay density fractions from sandy cropland soils with differing land-use history. Soil Sci Soc Am J 75:521-532 
Sokal RR, Rohlf JF (1981) Biometry. Freeman WH \& Co., New York

690 Sparling GP, Searle PL (1993) Dimethyl sulphoxide reduction as a sensitive indicator of microbial activity in soil: the relationship with microbial biomass and mineralization of nitrogen and sulphur. Soil Biol Biochem 25:251-256

Tabatabai MA (1984) Importance of sulfur in crop production. Biogeochem 1:45-62

Torsvik V, Øvreås L, Thingstad TF (2002) Prokaryotic diversity-Magnitude, 695 dynamics, and controlling factors. Science 296:1064-1066

Wen G, Schoenau JJ, Mooleki SP, Inanaga S, Yamamoto T, Hamamura K, Inoue M, An P (2003) Effectiveness of an elemental sulfur fertilizerin an oilseed-cereal-legume rotation on the Canadian Prairies. J Plant Nutr Soil Sci 166:54-60

Whitehead TR, Cotta MA (2004) Isolation and identification of hyper-ammonia producing bacteria from swine manure storage pits. Curr Microbiol 48:20-26

Wiegel J, Ljungdahl LG, Rawson JR (1979) Isolation from soil and properties of the extreme thermophile Clostridium thermohydrosulfuricum. J Bacteriol 139:800-810 


\section{Figure legends}

705 Figure 1. Sulfate concentrations during the growth of mesophilic (strain numbers 1 to 6) and thermophilic (strain numbers 7 to 12) isolates. Results correspond to samples at exponential phase (1 day; white bars) and stationary phase (8 days; grey bars) of growth.

710 Figure 2. Effect of temperature on the production of soluble sulfate by thermophilic isolates (strain numbers 7 to 12 ) at $50^{\circ} \mathrm{C}$ (grey bars), $60^{\circ} \mathrm{C}$ (black bars) and $70^{\circ} \mathrm{C}$ (white bars).

Figure 3. Effect of the addition of thiosulfate to the cultures of thermophilic isolates (strain numbers 7 to 12). Cultures with (grey bars) and without (white bars) supplemented thiosulfate were compared at their stationary phases of growth (8 days).

Figure 4. Soluble sulfate (A) and ammonium (B) concentration produced by natural bacterial soil assemblages incubated a $25^{\circ} \mathrm{C}$ and $50^{\circ} \mathrm{C}$ from three different Spanish locations: soil sample 1, Southwest (Carmona, Seville); soil sample 2, Northeastern pine forest (Aragon); soil sample 3A, Northeastern soil partially covered by weeds (Aragon); soil sample 3B, outlying area of Seville.

725 Figure 5. Sulfate (A and C) and ammonium (B and D) produced during the growth of thermophilic strain numbers 10 (A and B) and 12 (C and D) as a function of nutrient load (nutrient broth concentration) after 1 (white squares) and 6 (black squares) days of incubation at $50^{\circ} \mathrm{C}$.

730 Figure 6. Environmental measurements of temperature at surface (black squares), $2 \mathrm{~cm}$ below surface (grey squares), and air (white triangles) during a summer day in an Andalusian soil (Seville, Spain). 
Table 1.List of mesophilic and thermophilic isolates obtained during this study, their taxonomic classification, accession number for their $16 \mathrm{~S}$ rRNA gene sequences, similarity to closest homologue, sequence length, identification numbers, temperature of incubation during isolation, and optimum growth temperature for the thermophilic isolates. Strains numbers 10 and 12 show their accession numbers at the Spanish Type Culture Collection (CECT).

\begin{tabular}{|c|c|c|c|c|c|c|c|}
\hline $\begin{array}{l}\text { Strain } \\
\text { number }\end{array}$ & $\begin{array}{l}\text { Accession } \\
\text { number }\end{array}$ & $\begin{array}{l}\text { Incubation } \\
\text { temperature }\end{array}$ & $\begin{array}{l}\text { Taxonomic affiliation } \\
\text { Genus (Phylum) }\end{array}$ & $\begin{array}{l}\text { Closest homologue species } \\
\text { (Acc. No.) }\end{array}$ & Similarity \% & bp & $\begin{array}{l}\text { Optimum Growth } \\
\text { Temperature }\end{array}$ \\
\hline 1 & HQ730480 & $25^{\circ} \mathrm{C}$ & $\begin{array}{l}\text { Paenibacillus } \\
\text { (Firmicutes) }\end{array}$ & $\begin{array}{c}\text { P. lautus } \\
\text { (EU834247) }\end{array}$ & 97 & 863 & \\
\hline 2 & HQ730481 & $25^{\circ} \mathrm{C}$ & $\begin{array}{c}\text { Klebsiella } \\
\text { (Gammaproteobacteria) }\end{array}$ & $\begin{array}{c}\text { K. oxytoca } \\
\text { (GQ496665) }\end{array}$ & 100 & 855 & \\
\hline 3 & HQ730482 & $25^{\circ} \mathrm{C}$ & $\begin{array}{l}\text { Cellulosimicrobium } \\
\text { (Actinobacteria) }\end{array}$ & $\begin{array}{l}\text { C. cellulans } \\
\text { (GQ496666) }\end{array}$ & 100 & 804 & \\
\hline 4 & HQ730483 & $25^{\circ} \mathrm{C}$ & $\begin{array}{c}\text { Streptomyces } \\
\text { (Actinobacteria) }\end{array}$ & $\begin{array}{l}\text { S. variabilis } \\
\text { (EU741200) }\end{array}$ & 100 & 815 & \\
\hline 5 & HQ730484 & $25^{\circ} \mathrm{C}$ & $\begin{array}{l}\text { Neocosmospora } \\
\text { (Fungi) }\end{array}$ & $\begin{array}{l}\text { N. vasinfecta } \\
(\mathrm{AB} 302212)\end{array}$ & 94 & 558 & \\
\hline 6 & HQ730479 & $25^{\circ} \mathrm{C}$ & $\begin{array}{c}\text { Enterobacter } \\
\text { (Gammaproteobacteria) }\end{array}$ & $\begin{array}{l}\text { E. hormaechei } \\
\text { (HQ238703) }\end{array}$ & 99 & 757 & \\
\hline 7 & HQ730487 & $50^{\circ} \mathrm{C}$ & $\begin{array}{c}\text { Bacillus } \\
\text { (Firmicutes) }\end{array}$ & $\begin{array}{l}\text { B. thermoamylovorans } \\
\text { (FN397520) }\end{array}$ & 100 & 966 & $55-60^{\circ} \mathrm{C}$ \\
\hline 8 & HQ730488 & $50^{\circ} \mathrm{C}$ & $\begin{array}{l}\text { Geobacillus } \\
\text { (Firmicutes) }\end{array}$ & $\begin{array}{l}\text { G. kaustophilus } \\
\text { (JN036603) }\end{array}$ & 99 & 650 & $60^{\circ} \mathrm{C}$ \\
\hline 9 & HQ730489 & $50^{\circ} \mathrm{C}$ & $\begin{array}{l}\text { Geobacillus } \\
\text { (Firmicutes) }\end{array}$ & $\begin{array}{l}\text { G. thermoleovorans } \\
\text { (EU214614) }\end{array}$ & 99 & 782 & $60^{\circ} \mathrm{C}$ \\
\hline $\begin{array}{c}10 ; \\
\text { CECT7629 }\end{array}$ & HQ730490 & $50^{\circ} \mathrm{C}$ & $\begin{array}{l}\text { Brevibacillus } \\
\text { (Firmicutes) }\end{array}$ & $\begin{array}{l}\text { B. thermoruber } \\
\text { (DQ011668) }\end{array}$ & 99 & 903 & $50-60^{\circ} \mathrm{C}$ \\
\hline 11 & HQ730485 & $50^{\circ} \mathrm{C}$ & $\begin{array}{l}\text { Geobacillus } \\
\text { (Firmicutes) }\end{array}$ & $\begin{array}{l}\text { G. thermoleovorans } \\
\text { (EU214614) }\end{array}$ & 99 & 645 & $60^{\circ} \mathrm{C}$ \\
\hline $\begin{array}{c}12 ; \\
\text { CECT7628 }\end{array}$ & HQ730486 & $50^{\circ} \mathrm{C}$ & $\begin{array}{l}\text { Ureibacillus } \\
\text { (Firmicutes) }\end{array}$ & $\begin{array}{l}\text { U. thermosphaericus } \\
\text { (AF403019) }\end{array}$ & 97 & 656 & $50^{\circ} \mathrm{C}$ \\
\hline
\end{tabular}


Table 2. Relative RNA analysis by quantitative RT-PCR targeting thermophilic Firmicutes of the studied genera (thermophilic Bacillus, Brevibacillus and Ureibacillus, and Geobacillus) in samples collected at different temperatures from several Spanish locations.

\begin{tabular}{|c|c|c|c|}
\hline Sample & $\begin{array}{c}\text { Temperature } \\
\left({ }^{\circ} \mathrm{C}\right)\end{array}$ & Primer set & Percentage of \\
\hline Pine forest, Aragon (NE) & 38 & GeobacF-GeobacR & $0.730(0.143)$ \\
\hline Soil partially covered by & 40 & GeobacF-GeobacR & $0.029(0.001)$ \\
weeds, Aragon (NE) & & & \\
\hline Carmona, Seville (SW) & 58 & GeobacF-GeobacR & $0.134(0.022)$ \\
\hline Outlying area, Seville (SW) & 62 & GeobacF-GeobacR & $3.140(0.494)$ \\
\hline Outlying area, Seville (SW) & 22 & Geo485F, B-U485F, 518R & $0.330(0.033)$ \\
\hline Outlying area, Seville (SW) & 44 & Geo485F, B-U485F, 518R & $1.060(0.068)$ \\
\hline Outlying area, Seville (SW) & 31 & Geo485F, B-U485F, 518R & $0.691(0.042)$ \\
\hline Outlying area, Seville (SW) & 34 & Geo485F, B-U485F, 518R & $0.728(0.016)$ \\
\hline
\end{tabular}

1 The location area within Spain is indicated between brackets. NE, Northeast; SW, Southwest.

2 Percentage of RNA corresponding to thermophilic Firmicutes (thermophilic Bacillales) with respect to total bacterial RNA in the natural communities. SD between brackets. 
Figure 1

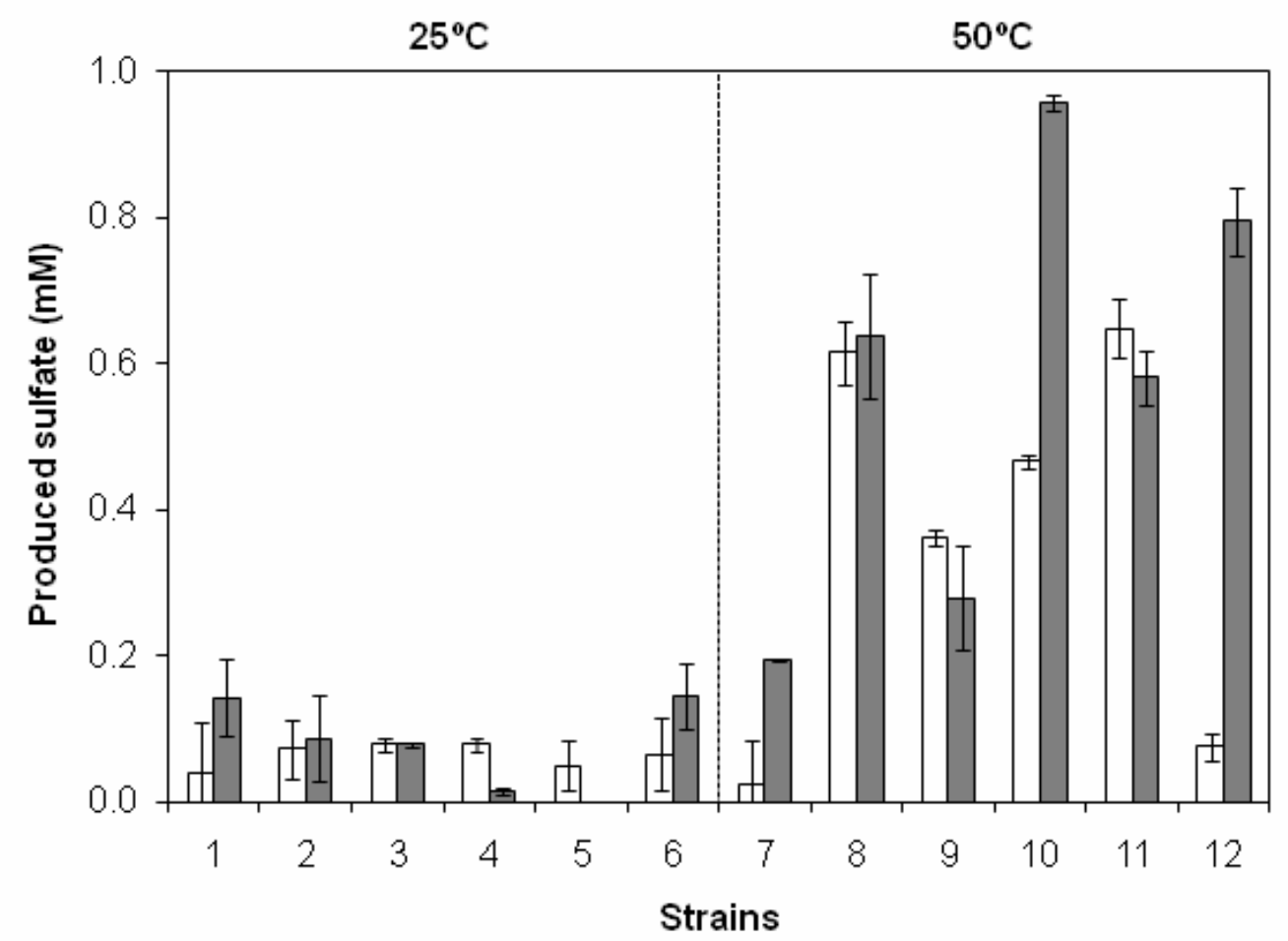


Figure 2

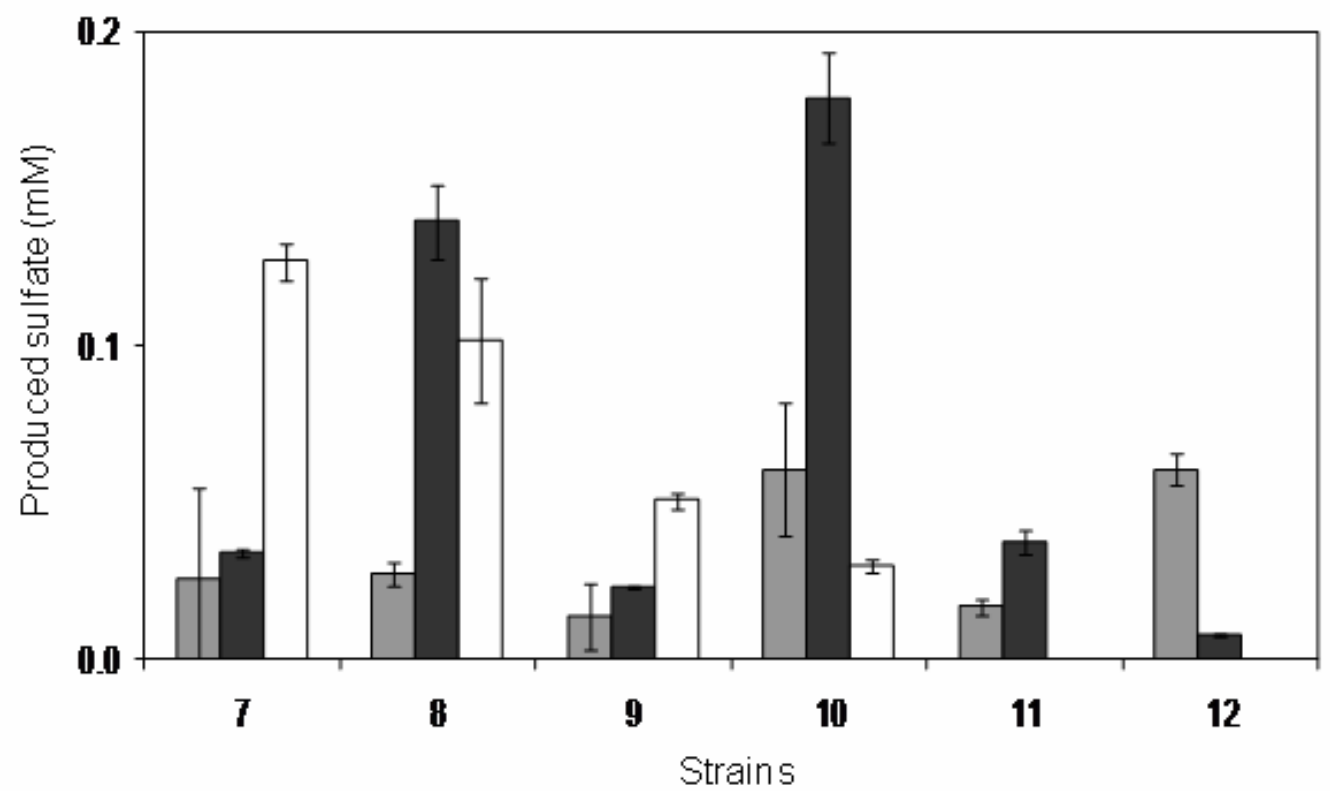


Figure 3

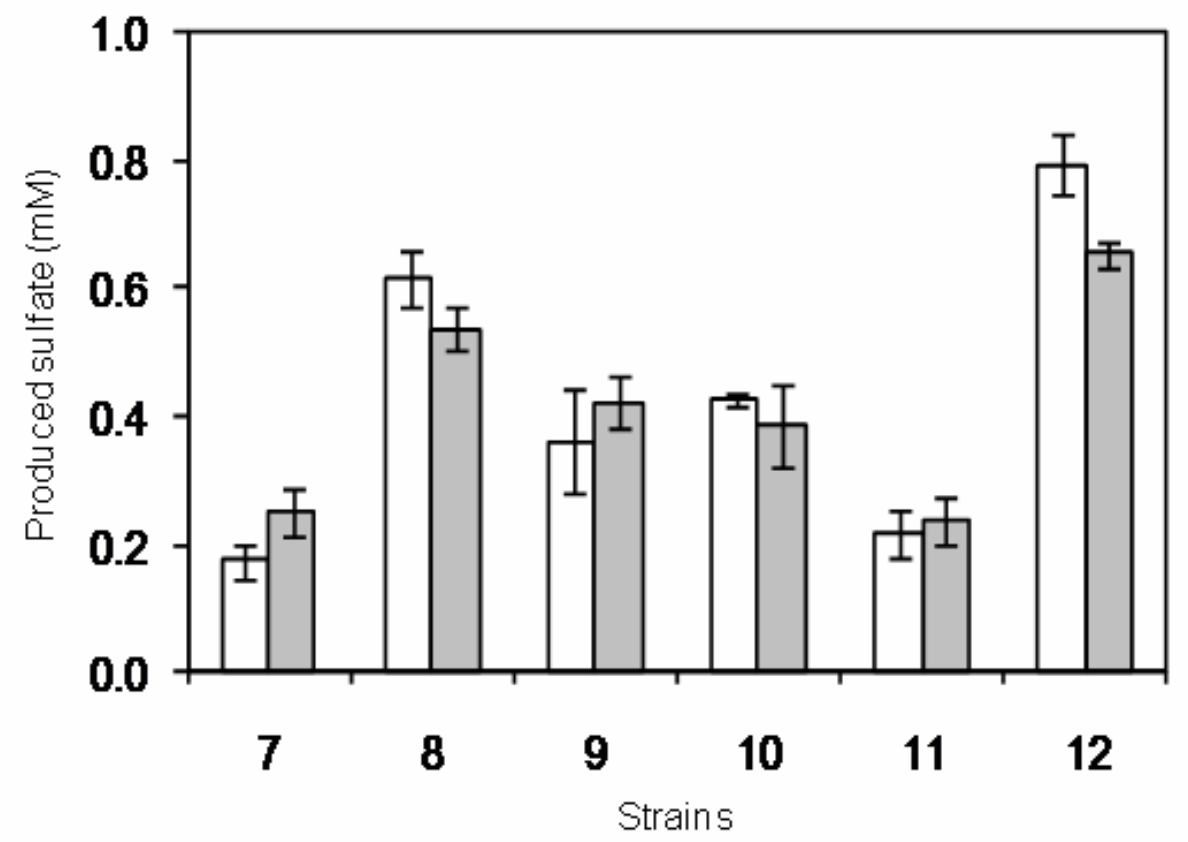


Figure 4

A
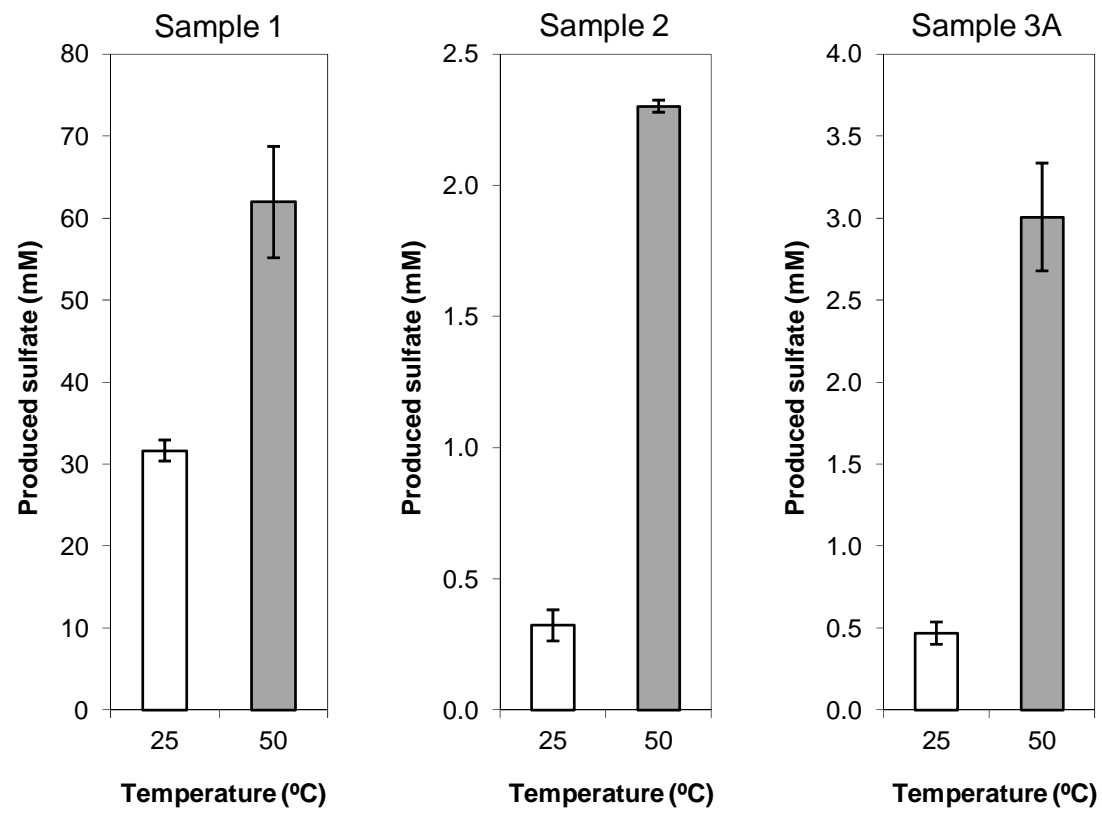

B
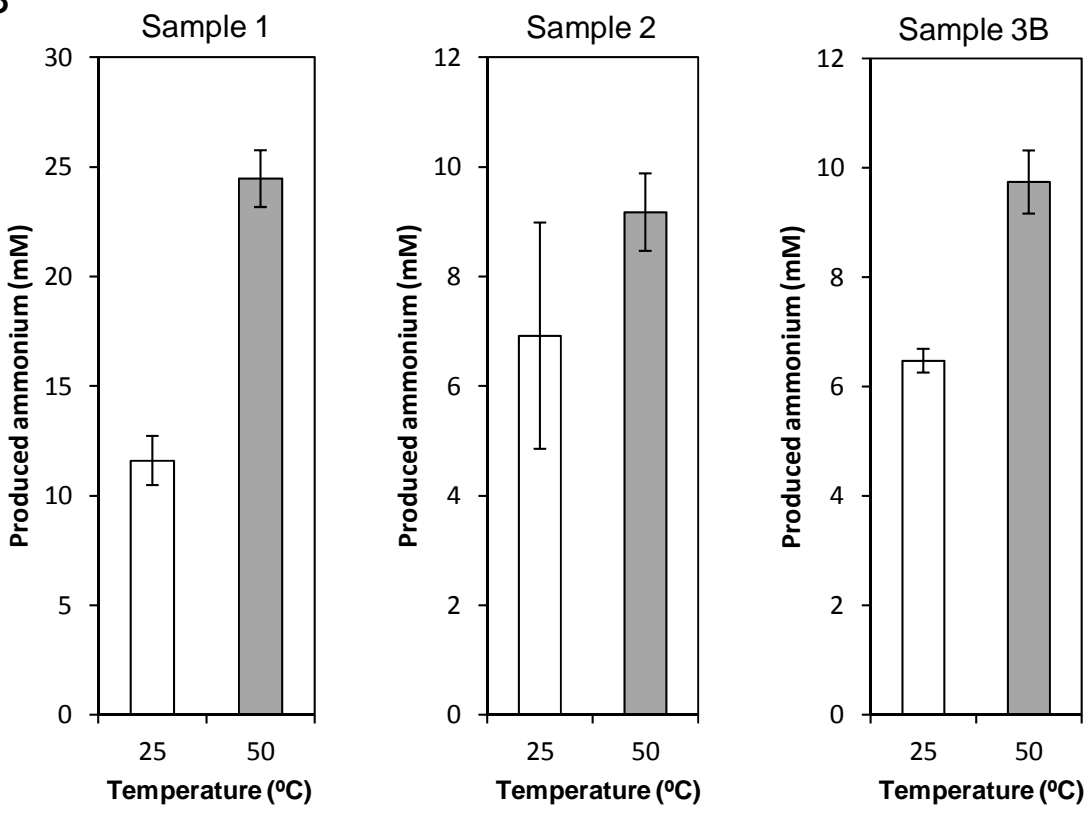
Figure 5
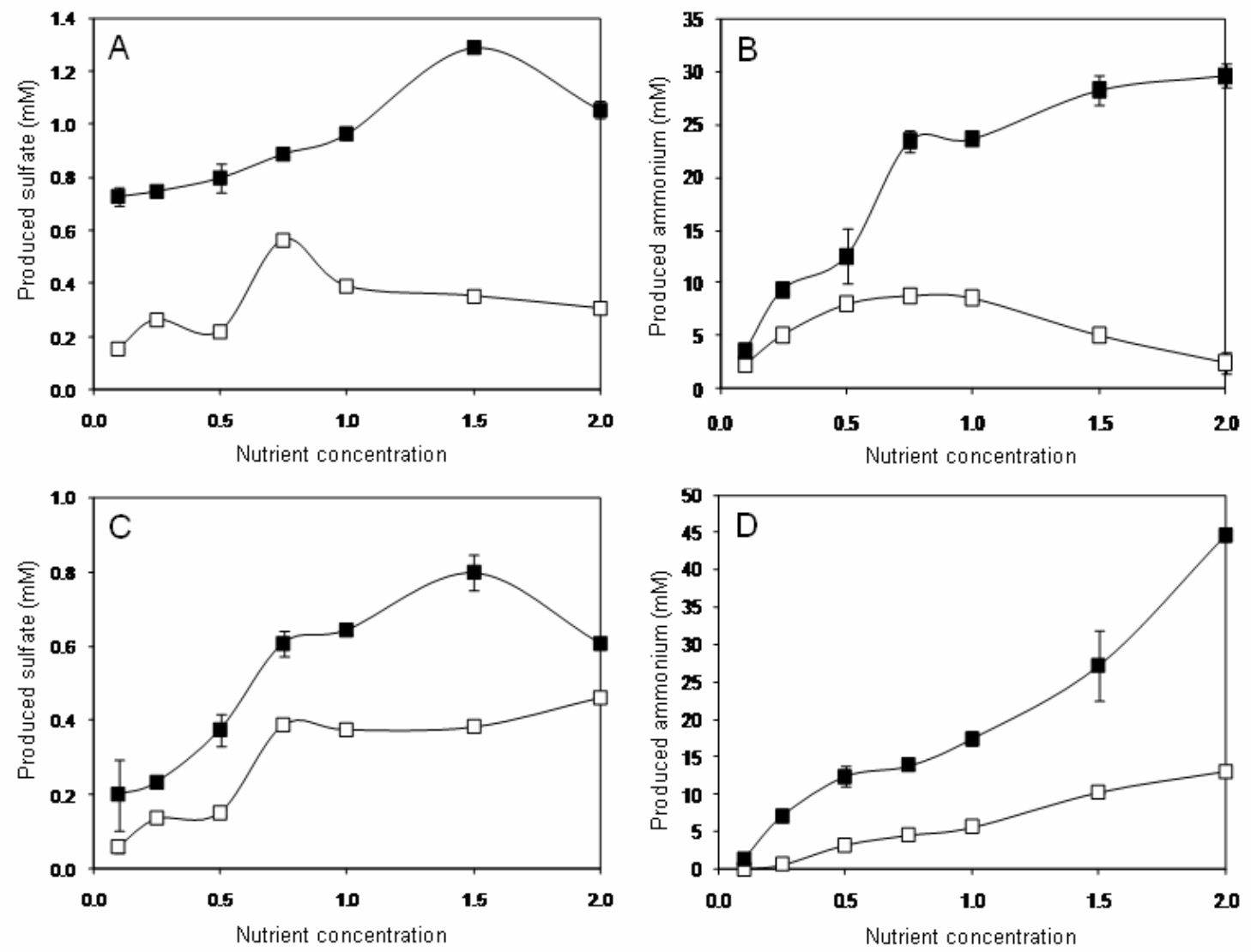
Figure 6

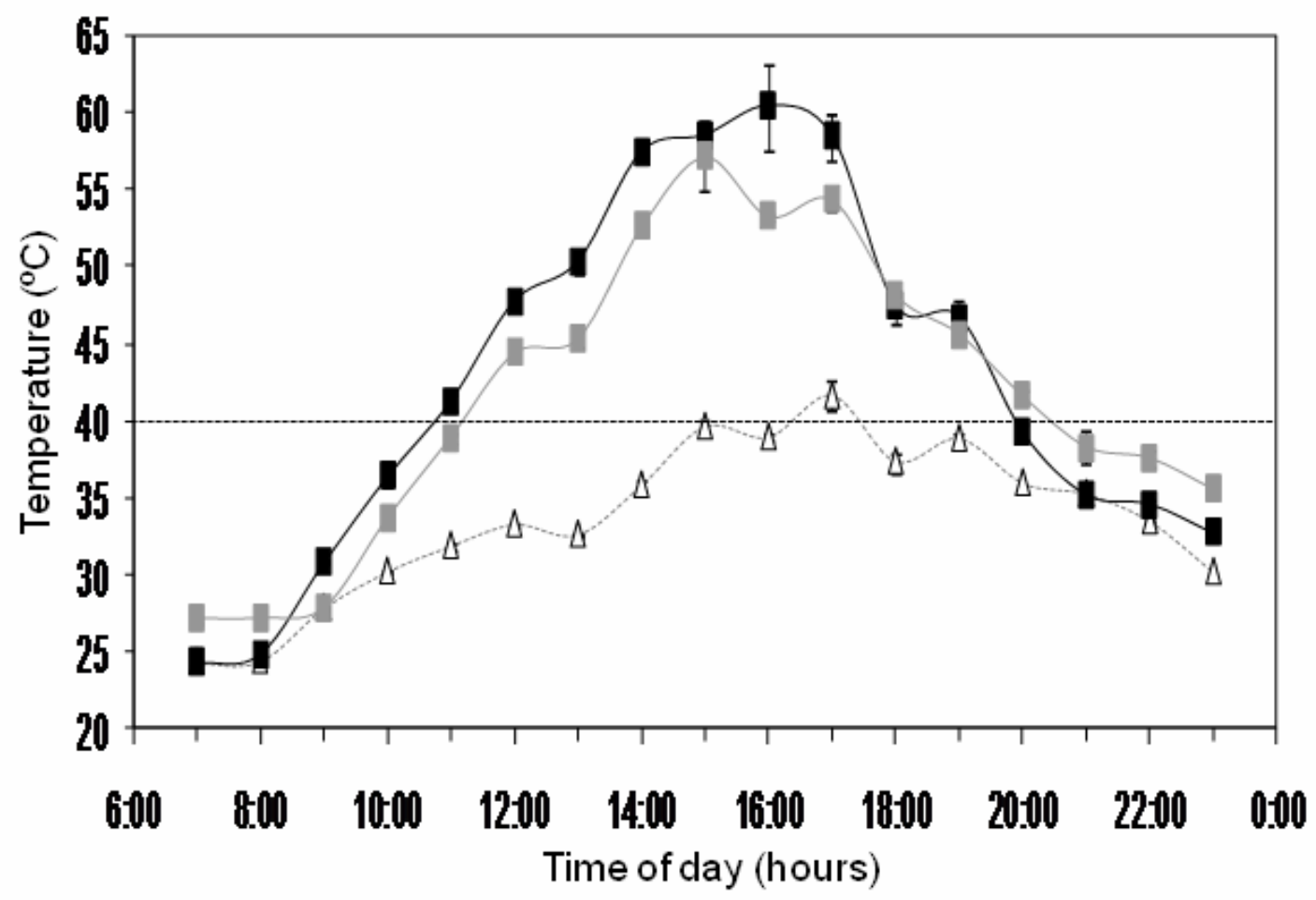

